\title{
Factors associated with stunting and overweight in Amazonian children: a population-based, cross-sectional study
}

\author{
Fernanda Cobayashi ${ }^{1}$, Rosângela Aparecida Augusto ${ }^{1}$, Bárbara Hatzlhoffer Lourenço ${ }^{1}$, \\ Pascoal Torres Muniz ${ }^{2}$ and Marly Augusto Cardoso 1,3,* \\ 'Public Health Nutrition Program, Department of Nutrition, School of Public Health, University of São Paulo, \\ São Paulo, Brazil: ${ }^{2}$ Department of Health Sciences, Federal University of Acre, Rio Branco, Brazil: ${ }^{3}$ Department of \\ Nutrition, School of Public Health, University of São Paulo, Av. Dr Arnaldo 715, 01246-904 São Paulo, Brazil
}

Submitted 11 June 2012: Final revision received 1 November 2012: Accepted 20 December 2012: First published online 4 March 2013

\begin{abstract}
Objective: To examine the prevalence of stunting and overweight in children and identify demographic, socio-economic and maternal characteristics, as well as biochemical indicators, associated with these outcomes.

Design: A population-based, cross-sectional study was performed. Data from structured questionnaires, anthropometric measurements, and blood and stool samples were used in Poisson regression models to estimate prevalence ratios (PR) according to a hierarchical conceptual framework.

Setting: Acrelândia, western Brazilian Amazon.

Subjects: Children $(n$ 1139) aged $<10$ years.

Results: Prevalence of stunting was $7 \cdot 1 \%$ (95\% CI 5.1, 9.6\%) and 3.7\% (95\% CI $2 \cdot 4,5 \cdot 7 \%)$ among children aged $<5$ years and $\geq 5$ years, respectively; overweight was detected in 20.6\% (95\% CI 17.4, 24.2\%) and $9 \cdot 4 \%(95 \%$ CI $7 \cdot 2,12 \cdot 1 \%)$ of children aged $<5$ years and $\geq 5$ years, respectively. Among children $<5$ years of age, stunting was positively associated with the lowest maternal height tertile $(\mathrm{PR}=3 \cdot 09,95 \%$ CI $1 \cdot 26,7 \cdot 63)$, low birth weight $(\mathrm{PR}=2 \cdot 70,95 \%$ CI $1 \cdot 41,5 \cdot 19)$, diarrhoea for $\geq 3 \mathrm{~d}(\mathrm{PR}=2 \cdot 21,95 \% \mathrm{CI} 1 \cdot 03,4 \cdot 77)$ and geohelminth infections $(\mathrm{PR}=2 \cdot 53,95 \% \mathrm{CI} 1 \cdot 02,6 \cdot 13)$. Overweight in children $<5$ years of age was positively associated with caesarean delivery ( $\mathrm{PR}=1 \cdot 45,95 \% \mathrm{CI} 1 \cdot 02,2 \cdot 06)$, birth weight $\geq 3500 \mathrm{~g}(\mathrm{PR}=1 \cdot 82,95 \%$ CI $1 \cdot 30,2 \cdot 55)$ and Fe deficiency $(\mathrm{PR}=1 \cdot 64,95 \%$ CI $1 \cdot 07,2 \cdot 53)$. Among children aged $\geq 5$ years, land or livestock ownership $(\mathrm{PR}=1 \cdot 85,95 \% \mathrm{CI} 1 \cdot 07,3 \cdot 22)$, maternal overweight $(\mathrm{PR}=2 \cdot 06,95 \% \mathrm{CI} 1 \cdot 23,3 \cdot 47)$, high C-reactive protein concentration $(\mathrm{PR}=2 \cdot 43,95 \% \mathrm{CI} 1 \cdot 26,4 \cdot 70)$, vitamin A deficiency $(\mathrm{PR}=1 \cdot 97,95 \% \mathrm{CI} 1 \cdot 13,3 \cdot 41)$ and high serum TAG concentration (PR $=2 \cdot 16,95 \%$ CI $1 \cdot 27,3 \cdot 68)$ were associated with overweight.

Conclusions: Overweight was more prevalent than stunting, being associated with higher household wealth, maternal overweight, caesarean delivery, high birth weight, micronutrient deficiencies and high TAG concentration. Improvements in maternal and child health care with sustainable access to healthy food are necessary to reduce short- and long-term health complications related to overweight in this population.
\end{abstract}

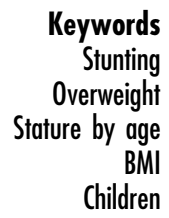

The prevalence of stunting (i.e. low length- or heightfor-age) from birth to 5 years has been decreasing worldwide, from $40 \%$ in 1990 to $27 \%$ in $2010^{(1)}$, and this rate is expected to fall further to $22 \%$ by 2020 . In Latin American countries, for instance, the prevalence of stunting in 2010 was $13.5 \%$ while a prevalence of $11.6 \%$ is predicted by the year $2015^{(1)}$.

In Brazil, there has been a $50 \%$ decline in stunting among children aged $<5$ years, from $13 \cdot 4 \%$ in 1996 to $6.7 \%$ in 2006, according to the most recent National Demographic and Health Survey ${ }^{(2)}$. Several contributory factors may explain this decline in the stunting prevalence, such as improvements in maternal schooling, increased purchasing power of low-income families, broader access to health services and the expansion of basic sanitation and water treatment ${ }^{(3)}$. However, owing to social inequalities among Brazilian regions, the north of the country, which encompasses the Amazon area, has notable financial difficulties and administrative, educational and nutritional deficiencies presenting important social and health inequities, explaining why the prevalence of stunting remains higher, affecting around $15 \%$ of children in this age group ${ }^{(2)}$. Concurrently, the incidence of overweight and obesity in children and adolescents is rising rapidly, becoming a major public health problem. Secular trend data on overweight status 
for Brazilian children aged 5-9 years, conducted by the Brazilian Institute of Geography and Statistics using BMI and the WHO classification as the diagnostic criteria, have shown that the prevalence of overweight in boys during the 1970 s was $10.9 \%$, increasing to $15.0 \%$ in the late 1980 s and attaining $34.8 \%$ in $2008-2009$. The prevalence of overweight among girls was $8 \cdot 6 \%, 11.9 \%$ and $32.0 \%$ for the same time periods, respectively. It is noteworthy that this trend of increasing overweight occurred across all income groups in both sexes ${ }^{(4)}$.

The pattern of shifts in nutritional status, characterized by persistence of stunting and increasing rates of overweight, typify the nutritional transition scenario found in many developing countries ${ }^{(5,6)}$. This transition process may be considered a particular public health concern when affecting children, since poor child growth can have important economic implications. Stunting in childhood is associated with fewer years of schooling and consequently low productivity at work $^{(7)}$. Overweight and obesity in childhood and adolescence have also been associated with increased risk of both premature mortality and adult morbidity ${ }^{(8)}$. Therefore, assessing nutritional status in childhood is essential for planning preventive actions, as evidenced by several studies showing that early exposure of children to malnutrition could be associated with changes in body composition during adolescence $^{(9,10)}$ and adulthood ${ }^{(8)}$.

Studies investigating the determinants of stunting and overweight have been conducted in developed and developing countries ${ }^{(11,12)}$, highlighting the importance of socio-economic status and maternal health factors. However, little is known about the influence of micronutrient deficiencies, inflammation indicators and dyslipidaemias on stunting or overweight among children ${ }^{(13,14)}$.

Therefore, in the present study, socio-economic and maternal characteristics as well as biochemical indicators were assessed in relation to both outcomes - stunting and overweight - in childhood. To our knowledge, it is the first population-based, cross-sectional study that describes the prevalence and factors associated with stunting and overweight in children $<10$ years of age living in an urban area of a town in the western Brazilian Amazon.

\section{Methods}

\section{Study design and population}

The present population-based, cross-sectional study on child nutrition and health was performed in December 2007 in Acrelândia, a frontier town located $112 \mathrm{~km}$ from Rio Branco, the capital of the state of Acre, in the western Brazilian Amazon region. At the time of the study, Acrelândia had 11520 inhabitants (44\% residing in the urban area), predominantly migrants from south-eastern and southern regions of Brazil, engaged in commercial agriculture and raising cattle. Infant mortality was estimated as 71/1000 live births in 2000, substantially higher than the national average (28/1000 live births). The human development index (for ranking municipalities in terms of health, education and income levels, reported by the United Nations Program for Development) in Acrelândia was estimated at $0 \cdot 680$ according to data from 2000 (ranged from 0.359 to 0.919 for Brazilian cities) ${ }^{(15)}$.

Sampling strategies and field procedures were reported previously $^{(16)}$. Briefly, all households from the urban area with children up to 10 years of age $(n 749)$ were identified with the assistance of local health workers of the Family Health Program of the Brazilian Ministry of Health. Thus, 1225 eligible children living in 734 households were enrolled ( $98.0 \%$ of households identified). A structured questionnaire was administered through face-to-face interview to the mothers or guardians of 1151 children (94.0\% of those eligible). The questionnaire was pilottested previously and covered the following topics: demographic and socio-economic status; environmental conditions; reproductive health variables; history of infant feeding practices (duration of total and exclusive breastfeeding, child's age at introduction of weaning foods); and the occurrence of morbidities, i.e. diarrhoea (three or more liquid stools within $24 \mathrm{~h}$ ), cough or fever up to $15 \mathrm{~d}$ prior to the interview, episodes of malaria and wheezing in the past 12 months and past hospitalization. After the interview, mothers and children were invited to visit the local family health clinic, where research assistants carried out a physical examination and trained phlebotomists obtained a venous blood sample from all children.

All parents or guardians of participating children provided written informed consent prior to enrolment. The study protocol was approved by the institutional review board of the School of Public Health, University of São Paulo, Brazil (no. 1681/07).

\section{Antbropometric assessment}

Length/height and weight were measured by trained research assistants following standardized procedures using calibrated equipment ${ }^{(17)}$. Among children aged $<2$ years, recumbent length was measured to the nearest millimetre with a locally made $1.3 \mathrm{~m}$-long infant measuring board with increments of $1 \mathrm{~mm}$; weight was measured to the nearest $10 \mathrm{~g}$ on an electronic paediatric scale (model 1583; Tanita, Tokyo, Japan). Children aged $\geq 2$ years were measured to the nearest millimetre with a stadiometer (model 208; SECA, Hamburg, Germany) affixed to the flat surface of a wall without a baseboard, perpendicular to the floor. For readings, children were positioned barefoot in a standing position in the middle of the stadiometer, with their head, shoulders, buttocks and heels against the wall. Weight was measured on an electronic scale (model HS-302; Tanita) and recorded to the nearest $100 \mathrm{~g}$. Maternal weight and height were subsequently measured by the research assistants by following the same standardized procedures $^{(17)}$. Each measurement was repeated and the mean value of the two measurements calculated. Birth date 
was recorded directly from birth certificates or child health cards. BMI was computed as weight in kilograms divided by the square of length/height in metres.

$Z$-scores for length/height-for-age (HAZ) and BMIfor-age (BAZ) were calculated according to WHO Child Growth Standards ${ }^{(18)}$ for children aged $0-5$ years and WHO Growth Reference Data ${ }^{(19)}$ for children aged $>5$ years. The cut-off for stunting was defined as $\mathrm{HAZ}<-2$. For the present analysis, overweight was defined as BAZ $>1$ including 'at risk of overweight', overweight and obesity for children $<5$ years old. Among children $\geq 5$ years old, overweight was defined as BAZ $>1^{(19,20)}$.

Maternal nutritional status was classified according to BMI categories ${ }^{(21)}$ as non-overweight (BMI $<25 \mathrm{~kg} / \mathrm{m}^{2}$ ) and overweight (BMI $\geq 25 \mathrm{~kg} / \mathrm{m}^{2}$ ), since only twenty-two mothers were underweight $\left(\mathrm{BMI}<18.5 \mathrm{~kg} / \mathrm{m}^{2}\right)$. Of the 1151 participants, one child had HAZ $>6$ and eleven children had missing data on weight or height. These children were excluded from the present analyses giving a final sample of 1139 children.

\section{Laboratory procedures}

A sample (approximately $5 \mathrm{ml}$ ) of fasting venous blood was collected from 1131 children (98.3\% of those eligible). At the field laboratory in Acrelândia, whole blood aliquots collected in EDTA-containing vacuum tubes were used to perform full blood cell counts and measure $\mathrm{Hb}$ concentrations on an ABX Micro60 automated cell counter (Horiba, Montpellier, France). A separate blood sample was protected from light and centrifuged within $1 \mathrm{~h}$ of collection. Plasma C-reactive protein (CRP) concentration was measured using the Immulite highsensitivity chemiluminescent assay (Diagnostic Products Corporation, Los Angeles, CA, USA). The cut-off for high CRP was $\geq 5 \mathrm{mg} / \mathrm{l}$ as an indicator of inflammation ${ }^{(22)}$. Serum lipid fractions were measured enzymatically using an automatic device (ADVIA 1650; Bayer, East Walpole, MA, USA). TAG concentrations $\geq 100 \mathrm{mg} / \mathrm{dl}$ were considered high according to age ${ }^{(23)}$. Anaemia, iron deficiency (ID) and iron-deficiency anaemia (IDA) were defined according to $\mathrm{Hb}$, serum ferritin (SF), serum transferrin receptor (sTfR) and CRP concentration, respectively ${ }^{(24)}$. The normal range of sTfR concentration, as determined by the immunoassay manufacturer, was $2 \cdot 9-8.3 \mathrm{mg} / \mathrm{l}$. ID was defined when SF concentrations were low $(<12 \mu \mathrm{g} / 1$ for children aged $<5$ years or $<15 \mu \mathrm{g} / 1$ for those aged $\geq 5$ years) or when sTfR concentrations were high $(>8.3 \mathrm{mg} / \mathrm{l})$. IDA was defined when ID occurred in anaemic children; the cut-off for $\mathrm{Hb}$ concentration considered was $110 \cdot 0 \mathrm{~g} / \mathrm{l}$ for children aged 6 months to 5 years, and $115.0 \mathrm{~g} / \mathrm{l}$ for children aged $\geq 5$ years. Plasma concentrations of vitamin A (retinol) were measured by the standard HPLC method ${ }^{(25)}$; concentrations $<0 \cdot 70 \mu \mathrm{mol} / 1$ defined vitamin A deficiency ${ }^{(26)}$. Children with anaemia or nutrient deficiencies detected during the survey received adequate treatment prescribed by the medical team involved in the project.
Stool samples were collected from 1016 children (97.0\% of those eligible) at the time of the interview, for subsequent analysis. Coprotest ${ }^{\circledR}$ cups containing a preservative solution $(10 \% \mathrm{w} / \mathrm{v}$ formalin) were provided for this purpose. All stool examinations were analysed to search for eggs, cysts and larvae of parasites, according to the qualitative technique of sedimentation ${ }^{(27)}$, as described elsewhere ${ }^{(16)}$. Geohelminths found in this population included Ascaris lumbricoides, Trichuris trichiura and Strongyloides stercoralis. Children with intestinal parasitic infections received free treatment prescribed by the research clinicians.

\section{Statistical analysis}

The main dichotomous dependent variables of interest were stunting and overweight. Explanatory variables comprised socio-economic, maternal and child characteristics as well as micronutrient deficiencies, inflammation and dyslipidaemia indicators.

Principal component analysis was used to derive a wealth index representing a proxy of household income ${ }^{(28)}$, based on the presence of twelve household assets, as described elsewhere ${ }^{(16)}$. To define socio-economic status, information on the wealth index and number of residents in each household was combined to generate variables of wealth concentration. Households were classified as low wealth concentration' when the wealth index was below the median and the number of residents was above the median for this population. On the other hand, for the overweight outcome, households were classified as 'high wealth concentration' when the wealth index was above the median and the number of residents was below the median. This combined variable was used when analysing associations for the stunting and overweight outcomes. Other socio-economic variables investigated were land or livestock ownership and maternal schooling, categorized as $<5$ years $v . \geq 5$ years. Maternal characteristics before pregnancy were maternal age at child's birth ( $<20$ years, $20-30$ years, $\geq 30$ years) and maternal height in tertiles $(<1.55 \mathrm{~m}, 1.55-1.59 \mathrm{~m}, \geq 1.59 \mathrm{~m})$. Maternal characteristics during pregnancy included the number of prenatal visits $(<6 v, \geq 6)$, smoking habits and caesarean delivery. Child's birth weight was categorized as $\leq 2500 \mathrm{~g}, 2501-3500 \mathrm{~g}$ or $\geq 3500 \mathrm{~g}$. Age at introduction of cow's milk was used as an indicator of infant feeding practices and was classified as $<3$ months or $\geq 3$ months based on the median age for weaning observed in our study population. Current care to child was assessed through the number of siblings $(<1 \quad v, \geq 2)$. Several morbidities were taken into account: duration of diarrhoea $<3 \mathrm{~d}$ or $\geq 3 \mathrm{~d}$, geohelminth infection and high CRP concentration. Finally, biochemical indicators of nutritional status included ID, IDA, vitamin A deficiency and high serum TAG concentration.

Children were stratified into two age categories $(<5$ years and $\geq 5$ years of age) based on sample size and distribution. 
First, we compared the distribution of baseline characteristics between the two age groups, using the Pearson $\chi^{2}$ test. Then for each age group, crude analyses were first conducted using Poisson regression models between the dependent variables of interest (stunting and overweight) and the explanatory variables, adjusting for sex and age. Adjusted prevalence ratios (PR) and 95\% confidence intervals were obtained for the factors associated with stunting and overweight using multiple Poisson regression models with robust variance according to a hierarchical conceptual framework $^{(29)}$. At each level of determination, covariates were retained in the model if they were associated with the outcome at $P<0 \cdot 10$ and for ordinal variables when they followed a dose-response pattern or if their inclusion in the model changed the PR by $10 \%$ or more. Missing observations were included in the multiple models by creating missing-value categories. All analyses were performed using the Stata statistical software package version $11 \cdot 0$.

\section{Results}

Among 1139 children studied, the mean age was $5 \cdot 13$ (sD 2.87) years (range: 3.02 months to 9.98 years). The distribution of the children between the age groups is shown in Table 1. The prevalence of stunting among children aged $<5$ years and $\geq 5$ years was $7 \cdot 1 \%$ (95\% CI $5 \cdot 1,9 \cdot 6 \%)$ and $3 \cdot 7 \%(95 \%$ CI $2 \cdot 4,5 \cdot 7 \%)$, respectively. The prevalence of overweight was $20 \cdot 6 \%$ (95\% CI 17·4, 24.2\%) in children $<5$ years of age and $9 \cdot 4 \%$ (95\% CI $7 \cdot 2,12 \cdot 1 \%)$ in the older ones. Children aged $<5$ years were more likely to have mothers who had more years of schooling, achieved more prenatal visits and realized more caesarean delivery. Children $<5$ years old also had a higher proportion of IDA, ID and high TAG concentrations when compared with children $\geq 5$ years of age (Table 1 ).

The investigation of the factors associated with stunting was performed only for children $<5$ years of age because of the low prevalence of stunting among older children $(3.7 \%)$. In the adjusted analysis, the lowest tertile of maternal height and low birth weight were positively associated with stunting, as were diarrhoea $\geq 3 \mathrm{~d}$ and geohelminth infection (Table 2).

Among children $<5$ years of age, high wealth concentration and caesarean delivery were positively associated with overweight in multiple models (Table 3 ). The prevalence of overweight among children with birth weight $\geq 3500 \mathrm{~g}$ was $85 \%$ higher compared with children whose weight was $<2500 \mathrm{~g}$ at birth $(P<0 \cdot 001)$. ID also remained positively associated with overweight after multiple adjustment.

Among children $\geq 5$ years of age, high wealth concentration and maternal schooling were no longer significantly associated with overweight in multiple models. However, prevalence of overweight was $85 \%$ higher among children whose families owned land or livestock compared with children from families not possessing these assets $(P=0 \cdot 02)$. After adjusting for this socio-economic variable, overweight among older children remained positively associated with maternal overweight $(P<0 \cdot 001)$. Vitamin A deficiency, as well as high CRP and TAG concentrations, was positively associated with the prevalence of overweight in the adjusted analysis (Table 3 ).

\section{Discussion}

Over past years, Acrelândia has shown a decreasing prevalence of stunting $(7 \cdot 1 \%)$ among pre-school children, since Souza et al. ${ }^{(30)}$, studying the same area in 2003 , found a prevalence of $10 \%$. Similar national trends have been observed by the latest Brazilian National Demographic and Health Survey ${ }^{(2)}$. Among children aged 5-10 years, the stunting prevalence of $3.7 \%$ in our study is approximately $50 \%$ lower than the national average found in the latest Brazilian Household Budget Survey $(6 \cdot 8 \%)^{(4)}$.

Brazil has shown declining trends of stunting based on national surveys since the 1970s. According to Monteiro et $a l^{(31)}$, the factors that contributed most to the decline of stunting (between 1996 and 2007) in Brazil were improvements in maternal schooling, increased purchasing power of low-income families and broader access to health services. It is noteworthy that from 2003 Brazil has reactivated the economic growth with improved income distribution, the expanding coverage of cash transfer programmes and also the Family Heath Program. The latter programme is targeted to poor households and covers health prevention and education ${ }^{(31)}$.

In the present study, maternal schooling was not associated with stunting related probably to the overall low literacy of the mothers ( $\sim 40 \%$ with less than 5 years of schooling). We found that low maternal height, low birth weight, diarrhoea $\geq 3 \mathrm{~d}$ and geohelminth infection remained positively associated with stunting in the multiple models.

As previously reported, maternal height is an important determinant of intra-uterine growth restriction ${ }^{(32)}$ and low birth weight ${ }^{(33)}$. Analysing data from fifty-four developing countries, Ozaltin et al. $^{(34)}$ found an inverse association between maternal height and infant mortality, low birth weight and stunting, suggesting that the effects of poor environmental conditions (inadequate nutrition, diseases) to which the mother was exposed can be transmitted to future generations.

Despite the routine distribution of anti-helminthic medication under the Family Health Program of the municipality $^{(35)}$, cases of children with episodes of diarrhoea and geohelminth infection were noted, and these variables were found to be associated with stunting. It has been suggested that this situation could be due to the lack of sanitation and water treatment in the area ${ }^{(35)}$. Moreover, it is known that infections worsen nutritional status especially among undernourished children ${ }^{(36)}$. 
Table 1 Characteristics of the study sample: urban children ( $n$ 1139) aged $<10$ years living in Acrelândia, western Brazilian Amazon, December 2007

\begin{tabular}{|c|c|c|c|c|c|c|c|}
\hline \multirow[b]{2}{*}{ Variable } & \multicolumn{2}{|c|}{ Total sample } & \multicolumn{2}{|c|}{$\begin{array}{l}\text { Children aged }<5 \text { years } \\
\qquad(n 557)\end{array}$} & \multicolumn{2}{|c|}{$\begin{array}{l}\text { Children aged } \geq 5 \text { years } \\
(\text { ( } 582)\end{array}$} & \multirow[b]{2}{*}{$P$} \\
\hline & $n$ & $\%$ & $n$ & $\%$ & $n$ & $\%$ & \\
\hline \multicolumn{8}{|l|}{ Gender } \\
\hline Male & 563 & $49 \cdot 4$ & 273 & $49 \cdot 0$ & 290 & $49 \cdot 8$ & $0 \cdot 783$ \\
\hline \multicolumn{8}{|l|}{ Nutritional status } \\
\hline Stunting & 62 & $5 \cdot 4$ & 40 & $7 \cdot 1$ & 22 & $3 \cdot 7$ & $0 \cdot 011$ \\
\hline Overweight & 170 & $14 \cdot 9$ & 115 & $20 \cdot 6$ & 55 & $9 \cdot 4$ & 0.000 \\
\hline \multicolumn{8}{|l|}{ Socio-economic characteristics } \\
\hline High wealth concentration* & 290 & $25 \cdot 6$ & 159 & $28 \cdot 5$ & 131 & $22 \cdot 5$ & $0 \cdot 019$ \\
\hline Low wealth concentrationt & 341 & $29 \cdot 9$ & 167 & $29 \cdot 9$ & 174 & $29 \cdot 9$ & 0.975 \\
\hline Owner of land or livestock & 203 & $17 \cdot 9$ & 95 & $17 \cdot 1$ & 108 & $18 \cdot 6$ & $0 \cdot 518$ \\
\hline Maternal schooling $\geq 5$ years & 674 & $61 \cdot 3$ & 353 & $66 \cdot 1$ & 321 & $56 \cdot 8$ & 0.002 \\
\hline \multicolumn{8}{|l|}{ Maternal characteristics } \\
\hline \multicolumn{8}{|l|}{ Maternal age at child's birth (years) } \\
\hline$<20$ & 301 & $29 \cdot 0$ & 121 & $23 \cdot 8$ & 180 & $34 \cdot 1$ & 0.001 \\
\hline 20-30 & 569 & 54.9 & 297 & $58 \cdot 4$ & 272 & $51 \cdot 6$ & \\
\hline$\geq 30$ & 165 & $15 \cdot 9$ & 90 & $17 \cdot 7$ & 75 & $14 \cdot 2$ & \\
\hline \multicolumn{8}{|l|}{ Maternal height tertile (m) } \\
\hline$<1.55$ & 319 & $32 \cdot 5$ & 157 & $31 \cdot 7$ & 162 & $33 \cdot 4$ & $0 \cdot 691$ \\
\hline $1.55-1.59$ & 326 & $33 \cdot 3$ & 171 & $34 \cdot 5$ & 155 & $32 \cdot 0$ & \\
\hline$\geq 1.59$ & 334 & $34 \cdot 1$ & 167 & $33 \cdot 7$ & 167 & $34 \cdot 5$ & \\
\hline \multicolumn{8}{|l|}{ Maternal characteristics during pregnancy } \\
\hline Number of prenatal visits $\geq 6$ & 698 & $77 \cdot 3$ & 382 & $82 \cdot 5$ & 316 & $71 \cdot 9$ & 0.000 \\
\hline Habitual smoker & 175 & $17 \cdot 5$ & 74 & $14 \cdot 8$ & 101 & $20 \cdot 1$ & 0.030 \\
\hline Caesarean delivery & 262 & $26 \cdot 0$ & 154 & $30 \cdot 9$ & 108 & $21 \cdot 1$ & 0.000 \\
\hline \multicolumn{8}{|l|}{ Child's characteristics at birth } \\
\hline \multicolumn{8}{|l|}{ Birth weight $(\mathrm{g})$} \\
\hline$<2500$ & 56 & $5 \cdot 5$ & 26 & $5 \cdot 0$ & 30 & $6 \cdot 1$ & 0.454 \\
\hline $2501-3500$ & 543 & $53 \cdot 8$ & 288 & $55 \cdot 6$ & 255 & $51 \cdot 9$ & \\
\hline$\geq 3500$ & 410 & $40 \cdot 6$ & 204 & $39 \cdot 3$ & 206 & $41 \cdot 9$ & \\
\hline \multicolumn{8}{|l|}{ Infant feeding practices } \\
\hline Age at cow's milk introduction $\leq 3$ months & 311 & $31 \cdot 8$ & 155 & $31 \cdot 4$ & 156 & $32 \cdot 2$ & 0.791 \\
\hline \multicolumn{8}{|l|}{ Current attention to child care } \\
\hline \multicolumn{8}{|l|}{ Number of siblings } \\
\hline 1 child & 176 & $17 \cdot 2$ & 127 & $25 \cdot 3$ & 49 & $9 \cdot 4$ & 0.000 \\
\hline$\geq 2$ children & 846 & $82 \cdot 7$ & 375 & $74 \cdot 7$ & 471 & $90 \cdot 5$ & \\
\hline \multicolumn{8}{|l|}{ Current maternal nutritional status } \\
\hline Maternal overweight & 446 & $45 \cdot 8$ & 229 & $46 \cdot 4$ & 217 & $45 \cdot 2$ & 0.697 \\
\hline \multicolumn{8}{|l|}{ Morbidities } \\
\hline \multicolumn{8}{|l|}{ Duration of diarrhoea $(d) \ddagger$} \\
\hline$<1$ & 924 & $82 \cdot 6$ & 409 & $75 \cdot 4$ & 515 & $89 \cdot 4$ & $0 \cdot 000$ \\
\hline $1-3$ & 118 & $10 \cdot 5$ & 73 & $13 \cdot 4$ & 45 & $7 \cdot 8$ & \\
\hline$\geq 3$ & 76 & $6 \cdot 8$ & 60 & $11 \cdot 0$ & 16 & $2 \cdot 7$ & \\
\hline Geohelminth infection & 38 & $3 \cdot 7$ & 11 & $2 \cdot 2$ & 27 & $5 \cdot 2$ & 0.014 \\
\hline High CRP concentration ( $\geq 5$ mg/l) & 100 & 9.5 & 56 & $11 \cdot 3$ & 44 & $7 \cdot 9$ & 0.063 \\
\hline Biochemical nutritional indicators $\S$ & & & & & & & \\
\hline ID & 502 & $45 \cdot 2$ & 347 & $65 \cdot 1$ & 155 & $26 \cdot 8$ & 0.000 \\
\hline IDA & 112 & $10 \cdot 3$ & 96 & $18 \cdot 8$ & 16 & $2 \cdot 7$ & 0.000 \\
\hline Vitamin A deficiency $(<0 \cdot 70 \mu \mathrm{mol} / \mathrm{l})$ & 147 & $14 \cdot 1$ & 65 & $13 \cdot 4$ & 82 & $14 \cdot 7$ & 0.559 \\
\hline High TAG concentration ( $\geq 100 \mathrm{mg} / \mathrm{dl})$ & 268 & $29 \cdot 7$ & 156 & $38 \cdot 9$ & 112 & $22 \cdot 4$ & 0.000 \\
\hline
\end{tabular}

ID, iron deficiency; IDA, iron-deficiency anaemia.

Totals may be less than 1139 due to missing values. $P$ values from $\chi^{2}$ tests for comparisons between age groups.

${ }^{*}$ Combination of wealth index above the median plus number of residents below the median.

tCombination of wealth index below the median plus number of residents above the median.

‡Defined by three or more liquid stools within $24 \mathrm{~h}$.

$\S$ ID was defined when serum ferritin concentration was $<12 \mu \mathrm{g} / \mathrm{l}$ for children aged $<5$ years or $<15 \mu \mathrm{g} / \mathrm{l}$ for those aged $\geq 5$ years or when serum transferrin receptor concentration was high ( $>8.3 \mathrm{mg} / \mathrm{l})$. IDA was defined when ID occurred in anaemic children; the cut-off for Hb concentration was $110.0 \mathrm{~g} / \mathrm{l}$ for children aged 6 months to 5 years, and $115.0 \mathrm{~g} / \mathrm{l}$ for children $\geq 5$ years.

In our study, we did not find an association between stunting and risk for overweight in the children. Meanwhile, prospective studies from developing countries have shown that adolescents who were stunted in childhood tended to gain less lean body mass and more fat mass than their non-stunted counterparts ${ }^{(37)}$. However, the body fat distribution is more likely to be central, a significant important risk factor for chronic diseases ${ }^{(38)}$. One of the potential underlying mechanisms involved in the maintenance of energy balance is the low rate of fat oxidation, which means in turn that the oxidized fat must be stored, thus favouring fat accumulation in the body ${ }^{(38)}$. 
Table 2 Factors associated with stunting in urban children ( $n$ 557) aged $<5$ years living in Acrelândia, western Brazilian Amazon, December 2007

\begin{tabular}{|c|c|c|c|c|c|c|}
\hline \multirow[b]{2}{*}{ Variable } & \multicolumn{3}{|c|}{ Crude } & \multicolumn{3}{|c|}{ Adjusted* $^{*}$} \\
\hline & PR & $95 \% \mathrm{Cl}$ & $P$ & PR & $95 \% \mathrm{Cl}$ & $P$ \\
\hline \multicolumn{7}{|l|}{ Wealth concentration } \\
\hline High wealth concentrationt & $1 \cdot 00$ & Ref. & - & $1 \cdot 00$ & Ref. & - \\
\hline Low wealth concentration¥ & $1 \cdot 60$ & $0 \cdot 87,2 \cdot 87$ & $0 \cdot 13$ & $1 \cdot 49$ & $0 \cdot 80,2 \cdot 84$ & 0.22 \\
\hline \multicolumn{7}{|l|}{ Maternal schooling (years) } \\
\hline$\geq 5$ & 1.00 & Ref. & - & $1 \cdot 00$ & Ref. & - \\
\hline$>5$ & 0.64 & $0 \cdot 34,1 \cdot 21$ & $0 \cdot 18$ & $0 \cdot 70$ & $0 \cdot 40,1 \cdot 32$ & 0.30 \\
\hline \multicolumn{7}{|l|}{ Maternal age at child's birth (years) } \\
\hline$<30$ & $1 \cdot 00$ & Ref. & - & $1 \cdot 00$ & Ref. & - \\
\hline$\geq 30$ & 1.98 & $0.93,3.89$ & 0.07 & $1 \cdot 65$ & $0 \cdot 86,3 \cdot 20$ & $0 \cdot 13$ \\
\hline \multicolumn{7}{|l|}{ Maternal height $(\mathrm{m})$} \\
\hline$\geq 1.59$ & $1 \cdot 00$ & Ref. & - & $1 \cdot 00$ & Ref. & - \\
\hline $1 \cdot 55-1.59$ & $1 \cdot 76$ & $0 \cdot 66,4 \cdot 73$ & 0.33 & $1 \cdot 70$ & $0 \cdot 61,4 \cdot 71$ & $0 \cdot 30$ \\
\hline$<1.55$ & $3 \cdot 50$ & $1 \cdot 44,8 \cdot 44$ & 0.00 & 3.09 & $1 \cdot 26,7 \cdot 63$ & $0 \cdot 01$ \\
\hline$P$ for trend & \multicolumn{3}{|c|}{0.02} & \multicolumn{2}{|c|}{0.01} & \\
\hline \multicolumn{7}{|l|}{ Birth weight $(\mathrm{g})$} \\
\hline $2500-3500$ & $1 \cdot 00$ & Ref. & - & $1 \cdot 00$ & Ref. & - \\
\hline$\geq 3500$ & $0 \cdot 17$ & $0.05,0.55$ & 0.00 & $0 \cdot 18$ & $0.05,0.58$ & 0.00 \\
\hline$<2500$ & 3.63 & $2 \cdot 01,6 \cdot 57$ & 0.00 & $2 \cdot 70$ & $1 \cdot 41,5 \cdot 19$ & $0 \cdot 00$ \\
\hline$P$ for trend & \multirow{2}{*}{\multicolumn{3}{|c|}{0.44}} & \multicolumn{2}{|c|}{0.40} & \\
\hline Age at cow's milk introduction (months) & & & & & & \\
\hline$\geq 3$ & $1 \cdot 00$ & Ref. & - & $1 \cdot 00$ & Ref. & - \\
\hline$<3$ & $2 \cdot 03$ & $1 \cdot 08,3 \cdot 80$ & 0.02 & $1 \cdot 44$ & $0 \cdot 80,2 \cdot 60$ & $0 \cdot 18$ \\
\hline \multicolumn{7}{|l|}{ Number of siblings } \\
\hline 1 child & $1 \cdot 00$ & Ref. & - & $1 \cdot 00$ & Ref. & - \\
\hline$\geq 2$ children & 1.94 & $0.81,4.63$ & $0 \cdot 13$ & $1 \cdot 77$ & $0 \cdot 73,4 \cdot 30$ & $0 \cdot 13$ \\
\hline \multicolumn{7}{|l|}{ Diarrhoea in past $15 d \S$} \\
\hline No & $1 \cdot 00$ & Ref. & - & $1 \cdot 00$ & Ref. & - \\
\hline Yes, during 1-2d & $1 \cdot 63$ & $0.74,3.63$ & 0.22 & $1 \cdot 16$ & $0.45,3.02$ & 0.75 \\
\hline Yes, during $\geq 3 \mathrm{~d}$ & $2 \cdot 51$ & $1 \cdot 20,5 \cdot 26$ & 0.01 & $2 \cdot 21$ & $1 \cdot 03,4 \cdot 77$ & 0.01 \\
\hline$P$ for trend & \multirow{2}{*}{\multicolumn{3}{|c|}{$0 \cdot 11$}} & \multicolumn{2}{|c|}{$0 \cdot 10$} & \\
\hline \multicolumn{6}{|l|}{ Geohelminth infection } & \\
\hline No & $1 \cdot 00$ & Ref. & - & $1 \cdot 00$ & Ref. & - \\
\hline Yes & $4 \cdot 61$ & $1 \cdot 98,10 \cdot 75$ & 0.00 & $2 \cdot 53$ & $1 \cdot 02,6 \cdot 31$ & 0.02 \\
\hline \multicolumn{7}{|l|}{ IDA } \\
\hline No & $1 \cdot 00$ & Ref. & - & $1 \cdot 00$ & Ref. & - \\
\hline Yes & $1 \cdot 83$ & $0 \cdot 91,3 \cdot 70$ & 0.08 & $1 \cdot 70$ & $0 \cdot 82,3 \cdot 73$ & 0.14 \\
\hline
\end{tabular}

PR, prevalence ratio; IDA, iron-deficiency anaemia; Ref. reference category.

*Variables were adjusted for others in the same or higher levels following the hierarchical conceptual framework

tCombination of wealth index above the median plus number of residents below the median.

$\ddagger$ Combination of wealth index below the median plus number of residents above the median.

$\S$ Diarrhoea was defined by three or more liquid stools within $24 \mathrm{~h}$.

This is of great concern, especially in countries undergoing nutrition transition.

In the present study, the socio-economic indicators of high wealth concentration and land or livestock ownership were positively associated with overweight among children aged $<5$ years and $\geq 5$ years, respectively. In their study of Colombian children from low- and middle-income families, McDonald et al. ${ }^{(39)}$ found that overweight was strongly associated with socio-economic status indicated by the possession of household assets. Similarly, in other developing countries, the best indicators of income were positively associated with overweight ${ }^{(40)}$. However, the opposite occurs in developed countries where socio-economic status is inversely associated with overweight ${ }^{(41)}$.

Other factors significantly associated with overweight in younger children in our study included caesarean delivery, high birth weight and ID. Children with caesarean delivery had greater risk of developing obesity in adulthood, as recently discussed in a study conducted by
Goldani et $a l .{ }^{(42)}$. The factors underlying this relationship remain unknown, but it has been suggested that the absence of breast-feeding in the first hours of life as a consequence of surgical delivery may be a risk factor for early weaning ${ }^{(43)}$ and consequently for the introduction of inadequate foods during the first years of life.

A significantly higher adjusted prevalence ratio for overweight was found among children weighing $\geq 3500 \mathrm{~g}$ at birth. High weight at birth has been associated with obesity in childhood $^{(44)}$ and also with metabolic syndrome in older children ${ }^{(45)}$. Obesity may be transmitted across generations as recently demonstrated by Cnattingius et al. in Swedish women ${ }^{(46)}$. Those authors found that the combination of an obese woman born large for gestational age increased the risk of her having a large-for-gestationalage infant compared with a non-obese woman whose birth weight was appropriate for gestational age ${ }^{(46)}$.

The association between ID and overweight in children $<5$ years of age found in the present study has been 
Table 3 Factors associated with overweight according to age group in urban children ( $n$ 1139) aged $<10$ years living in Acrelândia, western Brazilian Amazon, December 2007

\begin{tabular}{|c|c|c|c|c|c|c|c|c|c|c|c|c|}
\hline \multirow[b]{3}{*}{ Variable } & \multicolumn{6}{|c|}{ Children aged $<5$ years ( $n$ 557) } & \multicolumn{6}{|c|}{ Children aged $\geq 5$ years $(n 582)$} \\
\hline & \multicolumn{3}{|c|}{ Crude } & \multicolumn{3}{|c|}{ Adjusted $^{*}$} & \multicolumn{3}{|c|}{ Crude } & \multicolumn{3}{|c|}{ Adjusted* } \\
\hline & PR & $95 \% \mathrm{Cl}$ & $P$ & PR & $95 \% \mathrm{Cl}$ & $P$ & PR & $95 \% \mathrm{Cl}$ & $P$ & PR & $95 \% \mathrm{Cl}$ & $P$ \\
\hline \multicolumn{13}{|l|}{ Wealth concentration } \\
\hline High wealth concentrationt & 1.00 & Ref. & - & 1.00 & Ref. & - & 1.00 & Ref. & - & 1.00 & Ref. & - \\
\hline Low wealth concentration & $1 \cdot 41$ & $1 \cdot 01,1 \cdot 96$ & 0.04 & $1 \cdot 41$ & $1 \cdot 01,1 \cdot 96$ & 0.04 & $1 \cdot 81$ & $1 \cdot 08,3 \cdot 05$ & 0.02 & $1 \cdot 40$ & $0 \cdot 82,2 \cdot 40$ & $0 \cdot 22$ \\
\hline \multicolumn{13}{|l|}{ Land or livestock ownership } \\
\hline No & - & - & - & - & - & - & 1.00 & Ref. & - & $1 \cdot 00$ & Ref. & - \\
\hline Yes & - & - & - & - & - & - & $2 \cdot 06$ & $1 \cdot 20,3.56$ & 0.00 & $1 \cdot 85$ & $1 \cdot 07,3 \cdot 22$ & 0.02 \\
\hline \multicolumn{13}{|l|}{ Maternal schooling (years) } \\
\hline$<5$ & - & - & - & - & - & - & 1.00 & Ref. & - & $1 \cdot 00$ & Ref. & - \\
\hline$\geq 5$ & - & - & - & - & - & - & $1 \cdot 85$ & $1 \cdot 06,3.23$ & 0.03 & $1 \cdot 63$ & $0.93,2.85$ & 0.08 \\
\hline \multicolumn{13}{|c|}{ Maternal age at child's birth (years) } \\
\hline$\geq 30$ & $1 \cdot 00$ & Ref. & - & 1.00 & Ref. & - & - & - & - & - & - & - \\
\hline$<30$ & $1 \cdot 77$ & $1.01,3.09$ & 0.04 & $1 \cdot 70$ & $0.97,2.96$ & 0.06 & - & - & - & - & - & - \\
\hline \multicolumn{13}{|l|}{ Number of prenatal visits } \\
\hline$<6$ & 1.00 & Ref. & - & $1 \cdot 00$ & Ref. & - & - & - & - & - & - & - \\
\hline$\geq 6$ & $1 \cdot 77$ & $0.96,3.25$ & 0.06 & 1.60 & $0.86,2.94$ & $0 \cdot 14$ & - & - & - & - & - & - \\
\hline \multicolumn{13}{|l|}{ Caesarean delivery } \\
\hline No & 1.00 & Ref. & - & 1.00 & Ref. & - & - & - & - & - & - & - \\
\hline Yes & $1 \cdot 52$ & $1 \cdot 07,2 \cdot 17$ & 0.01 & 1.45 & $1 \cdot 02,2 \cdot 06$ & 0.02 & - & - & - & - & - & - \\
\hline \multicolumn{13}{|l|}{ Birth weight $(\mathrm{g}) \ddagger$} \\
\hline $2500-3500$ & 1.00 & Ref. & - & $1 \cdot 00$ & Ref. & - & - & - & - & - & - & - \\
\hline$\geq 3500$ & $1 \cdot 74$ & $1 \cdot 24,2 \cdot 45$ & 0.00 & $1 \cdot 82$ & $1 \cdot 30,2 \cdot 55$ & 0.00 & - & - & - & - & - & - \\
\hline$<2500$ & 0.95 & $0 \cdot 37,2 \cdot 40$ & 0.91 & $1 \cdot 02$ & $0 \cdot 40,2 \cdot 60$ & 0.95 & - & - & - & - & - & - \\
\hline$P$ for trend & \multicolumn{3}{|c|}{0.30} & \multicolumn{3}{|c|}{0.27} & & & & & & \\
\hline \multicolumn{13}{|l|}{ Number of siblings } \\
\hline$\geq 2$ children & $1 \cdot 00$ & Ref. & - & $1 \cdot 00$ & Ref. & - & - & - & - & - & - & - \\
\hline 1 child & 1.59 & $1 \cdot 11,2 \cdot 24$ & 0.01 & $1 \cdot 41$ & $0.99,2.03$ & 0.05 & - & - & - & - & - & - \\
\hline \multicolumn{13}{|l|}{ Maternal BMI $\left(\mathrm{kg} / \mathrm{m}^{2}\right)$} \\
\hline$<25$ & - & - & - & - & - & - & 1.00 & Ref. & - & 1.00 & Ref. & - \\
\hline$\geq 25$ & - & - & - & - & - & - & $2 \cdot 16$ & $1 \cdot 30,3 \cdot 70$ & 0.00 & $2 \cdot 06$ & $1 \cdot 23,3 \cdot 47$ & 0.00 \\
\hline \multicolumn{13}{|l|}{ CRP concentration (mg/l) } \\
\hline$<5$ & - & - & - & - & - & - & $1 \cdot 00$ & Ref. & - & $1 \cdot 00$ & Ref. & - \\
\hline$\geq 5$ & - & - & - & - & - & - & $2 \cdot 06$ & $1 \cdot 03,4 \cdot 10$ & 0.03 & $2 \cdot 43$ & $1 \cdot 26,4 \cdot 70$ & 0.00 \\
\hline \multicolumn{13}{|l|}{ ID } \\
\hline No & $1 \cdot 00$ & Ref. & - & $1 \cdot 00$ & Ref. & - & - & - & - & - & - & - \\
\hline Yes & $1 \cdot 70$ & $1 \cdot 11,2 \cdot 60$ & 0.01 & $1 \cdot 64$ & $1 \cdot 07,2 \cdot 53$ & 0.02 & - & - & - & - & - & - \\
\hline \multicolumn{13}{|l|}{ Vitamin A $(\mu \mathrm{mol} / \mathrm{l})$} \\
\hline$\geq 0 \cdot 70$ & - & - & - & - & - & - & $1 \cdot 00$ & Ref. & - & $1 \cdot 00$ & Ref. & - \\
\hline $\begin{array}{l}<0 \cdot 70 \\
\text { TAG concentration (mg/l) }\end{array}$ & - & - & - & - & - & - & $1 \cdot 90$ & $1 \cdot 05,3 \cdot 40$ & 0.03 & $1 \cdot 97$ & $1 \cdot 13,3 \cdot 41$ & 0.01 \\
\hline$<100$ & - & - & - & - & - & - & $1 \cdot 00$ & Ref. & - & $1 \cdot 00$ & Ref. & - \\
\hline$\geq 100$ & - & - & - & - & - & - & $2 \cdot 03$ & $1 \cdot 15,3 \cdot 60$ & 0.01 & $2 \cdot 16$ & $1 \cdot 27,3 \cdot 68$ & 0.00 \\
\hline
\end{tabular}

PR, prevalence ratio; CRP, C-reactive protein; ID, iron deficiency; Ref. reference category.

Variables were adjusted for others in the same or higher levels following the hierarchical conceptual framework.

Combination of wealth index above the median plus number of residents below the median.

Combination of wealth index below the median plus number of residents above the median. 
previously documented ${ }^{(47)}$. Several hypotheses have been proposed to explain this association, such as the increased plasma volume in obese individuals and inadequate intake of nutrients ${ }^{(48)}$. Another study however suggested that higher levels of hepcidin might be involved, since obesity is considered a low-grade inflammatory disease ${ }^{(49)}$. It is noteworthy that in the present study, sTfR concentration (in addition to SF) was used as a differential diagnosis of ID because this parameter is not affected by infectious processes $^{(50)}$. The poor quality of diet among the young Amazonian children studied is proposed as a likely hypothesis explaining this association. A previous study assessing the characteristics of diet among children $<2$ years of age in the same region indicated low consumption of fruit and vegetables, low consumption of Fe-rich foods and excessive consumption of cow's milk and porridge ${ }^{(51)}$.

For children aged $\geq 5$ years, having an overweight mother was strongly associated with overweight. This result is in line with the findings of other studies ${ }^{(39,52)}$. The association may be due to the intergenerational transmission of obesity ${ }^{(53)}$, as well as environmental and/ or behavioural factors, since parents play an important role in the development of their children's food preferences and energy intake ${ }^{(54)}$.

Our results also indicated that higher CRP concentrations were positively associated with overweight. Besides the hypothesis of low-grade inflammatory disease caused by excess weight ${ }^{(55)}$, this association may be explained by the presence of recurrent infections to which these Amazonian children are exposed.

In the present study, overweight children $\geq 5$ years of age were also more likely to have higher TAG concentration than their counterparts. This may be an indication of inadequacies in diet from an early age ${ }^{(51)}$. Abnormal levels of TAG have been well documented in the literature among children and adolescents with overweight status as an independent risk factor for $\mathrm{CVD}^{(8)}$.

Finally, in the present study vitamin A deficiency was positively associated with overweight in children aged $\geq 5$ years, after adjusting for high CRP and TAG concentrations. It is well known that vitamin A deficiency compromises growth and is associated with low resistance to infections ${ }^{(26)}$. This may be a relevant concern among children residing in the Brazilian Amazon region, where there is high exposure to numerous aetiological agents along with insufficient services of basic sanitation and water treatment. In addition, akin to the explanation for the association of ID and high TAG levels with overweight, the association of vitamin A deficiency and overweight could also be attributed to the poor quality diet of the study population. From an early age, this group has a low intake of fruit and vegetables and substantial consumption of unhealthy foods such as processed foods high in sodium, preservatives, sugars and fats, according to previous partial analysis from our data ${ }^{(51)}$. Changes in diet quality are characteristic of the nutritional transition faced by countries undergoing rapid economic development and improvement in living standards ${ }^{(6,56)}$. Overall, Brazilians have decreased their consumption of staple foods such as rice (decline of $40.5 \%$ ) and beans (decline of 26.4\%) from 2002 to 2008. The current consumption of fruits and vegetables reaches only one-quarter of WHO recommended levels. On the other hand, the consumption of soft drinks has risen by $39 \cdot 3 \%{ }^{(57)}$. Dietary patterns are established in childhood, persist into adulthood and are significantly associated with chronic disease risk factors ${ }^{(58)}$. Interestingly, a Chinese study suggested that mothers' nutritional knowledge, health consciousness and exposure to the media may influence their children's diet beyond the determining role of family resources and access to foods available to the community in developing countries undergoing rapid social and economic transition ${ }^{(59)}$.

Our study has several limitations that should be considered. Because of its cross-sectional design, caution should be taken in interpreting the present findings, since no causal assumptions can be made. Furthermore, the current analysis included no evaluation of indicators of dietary consumption and physical activity in the population studied due to related logistic and methodological issues. In Acrelândia, seasonality of dietary habits has been reported, requiring more recall days, spread across seasons and a period of months to lead a more accurate dietary estimates among school-aged children ${ }^{(60)}$; however, unfortunately, this was not feasible in the present study due to the field conditions and cross-sectional design. Despite these limitations, the present populationbased study used direct and standardized anthropometric measurements in both children and their mothers and employed a comprehensive set of biochemical indicators, thus contributing to the understanding of several socioeconomic, maternal and individual factors associated with stunting and overweight in children.

Concerted efforts have been made to increase access to food and to improve the health of Brazilian children through conditional cash transfer programmes and expansion of basic health care. While national programmes are in place to help prevent micronutrient deficiencies and promote healthy eating habits, there remains much work to be done - from infrastructure improvements to the integration of governmental organizations, nongovernmental organizations and civil society - in promoting and implementing healthy child growth initiatives.

\section{Conclusion}

The prevalence of overweight was higher than that of stunting among pre-school children in our study. Factors positively associated with stunting in children aged $<5$ years were low maternal height, low birth weight, diarrhoea episodes and geohelminth infection. For overweight, higher wealth concentration, caesarean delivery, high birth weight 
and ID proved important factors among children $<5$ years of age, whereas land or livestock ownership, maternal overweight, high CRP and TAG concentrations and vitamin A deficiency were associated factors among older children. These results point to the importance of intensifying the promotion of maternal and child health practices, as well as sustainable access to healthy food, in a bid to reduce shortand long-term complications in this population against a scenario of nutritional transition.

\section{Acknowledgements}

Sources offunding: The study was funded by the National Council for Scientific and Technological Development of Brazil (CNPq; grant nos. 551359/2001-3, 502937/2003-3, 307728/2006-4 and 470573/2007-4), the Fundação de Amparo à Pesquisa do Estado de São Paulo (FAPESP; grant no. 2007/53042-1) and the Coordenação de Aperfeiçoamento de Pessoal de Nível Superior (CAPES; Ministry of Education of Brazil). F.C. and R.A.A. received postdoctoral scholarships from CNPq and CAPES, respectively. B.H.L. received a PhD scholarship from FAPESP (grant no. 2008/ 57796-3). Conflicts of interest: The authors have no conflicts of interest to declare. Authors' contributions: M.A.C. and P.T.M. designed and conducted the research; F.C. and R.A.A. analysed the data; F.C., R.A.A. and B.H.L. wrote the paper. All authors read and approved the final manuscript. Acknowledgements: The authors are profoundly grateful to all children and their families who participated in the study, to the Municipality Health Service of Acrelândia, and to the field work research team for valuable assistance.

\section{References}

1. de Onis M, Blossner M \& Borghi E (2012) Prevalence and trends of stunting among pre-school children, 1990-2020. Public Health Nutr 15, 142-148.

2. Ministério da Saúde (2009) Pesquisa Nacional de Demografia e Saúde da criança e da mulher - Dimensões do processo reprodutivo e da saúde da criança. Brasília: Ministério da Saúde.

3. Instituto Brasileiro de Geografia e Estatística (2007) Pesquisa Nacional por Amostra de Domicílios. Sintese de indicadores. Rio de Janeiro: IBGE.

4. Instituto Brasileiro de Geografia e Estatística (2010) Pesquisa de Orçamentos Familiares 2008-2009. Antropometria e estado nutricional de crianças, adolescentes e adultos no Brasil. Rio de Janeiro: IBGE.

5. Kimani-Murage EW, Kahn K, Pettifor JM et al. (2010) The prevalence of stunting, overweight and obesity, and metabolic disease risk in rural South African children. BMC Public Health 10, 158.

6. Custodio E, Descalzo MA, Roche J et al. (2010) The economic and nutrition transition in Equatorial Guinea coincided with a double burden of over- and under nutrition. Econ Hum Biol 8, 80-87.

7. Grantham-McGregor S, Cheung YB, Cueto S et al. (2007) Developmental potential in the first 5 years for children in developing countries. Lancet 369, 60-70.

8. Reilly JJ \& Kelly J (2011) Long-term impact of overweight and obesity in childhood and adolescence on morbidity and premature mortality in adulthood: systematic review. Int J Obes (Lond) 35, 891-898.

9. Sterling R, Miranda J, Gilman RH et al. (2011) Early anthropometric indices predict short stature and overweight status in a cohort of Peruvians in early adolescence. Am J Phys Anthropol 148, 451-461.

10. Bénéfice E, Garnier D, Simondon KB et al. (2001) Relationship between stunting in infancy and growth and fat distribution during adolescence in Senegalese girls. Eur J Clin Nutr 55, 50-58.

11. Savva SC, Tornaritis M, Chadjigeorgiou C et al. (2005) Prevalence and socio-demographic associations of undernutrition and obesity among preschool children in Cyprus. Eur J Clin Nutr 59, 1259-1265.

12. El Taguri A, Betilmal I, Mahmud SM et al. (2009) Risk factors for stunting among under-fives in Libya. Public Health Nutr 12, 1141-1149.

13. Anderson VP, Jack S, Monchy D et al. (2008) Co-existing micronutrient deficiencies among stunted Cambodian infants and toddlers. Asia Pac J Clin Nutr 17, 72-79.

14. Best C, Neufingerl N, van Gell L et al. (2010) The nutritional status of school-aged children. Why should we care? Food Nutr Bull 31, 400-417.

15. United Nations Development Programme (2000) Human development index ranking of municipalities in Brazil 2003. http://www.pnud.org.br/atlas/ranking/IDH_Municipios_ Brasil_2000.aspx?indiceAccordion $=1 \& l i=1 i \_$Ranking2003 (accessed October 2012).

16. Cardoso MA, Scopel KK, Muniz PT et al. (2012) Underlying factors associated with anemia in Amazonian children: a population-based, cross-sectional study. PLoS One 7, e36341.

17. Lohman TG, Roche AF \& Martorell R (1988) Anthropometric Standardization Reference Manual. Champaign, IL: Human Kinetics Books.

18. WHO Multicentre Growth Reference Study Group (2006) WHO child growth standards based on length/height, weight and age. Acta Paediatr Suppl 450, 76-85.

19. de Onis M, Onyango AW, Borghi E et al. (2007) Development of a WHO growth reference for school aged children and adolescents. Bull World Health Organ 85, 660-667.

20. de Onis M \& Lobstein T (2010) Defining obesity risk status in the general childhood population: which cut-offs should we use? Int J Pediatr Obes 5, 458-460.

21. World Health Organization (1995) Physical Status: The Use and Interpretation of Anthropometric Indicators of Nutritional Status. WHO Technical Report Series no. 854. Geneva: WHO.

22. Thurnham DI, McCabe LD, Haldar S et al. (2010) Adjusting plasma ferritin concentrations to remove the effects of subclinical inflammation in the assessment of iron deficiency: a meta-analysis. Am J Clin Nutr 92, 546-555.

23. Kwiterovich PO (2008) Recognition and management of dyslipidemia in children and adolescents. J Clin Endocrinol Metab 93, 4200-4209.

24. World Health Organization (2007) Assessing the Iron Status of Populations, 2nd ed. Geneva: WHO.

25. Gomes LF, Alves AF, Sevanian A et al. (2004) Role of $\beta_{2}$-glycoprotein I, LDL-, and antioxidant concentrations in hypercholesterolemic elderly subjects. Antioxid Redox Signal 6, 237-244.

26. World Health Organization (2009) Global Prevalence of Vitamin A Deficiency in Populations at Risk 1995-2005. WHO Global Database on Vitamin A Deficiency. Geneva: WHO.

27. Hoffman WA, Pons JA \& Janer JL (1934) The sedimentation concentration method in Schistosomiasis mansoni. PR J Public Health Trop Med 9, 283-298.

28. Filmer D \& Pritchett LH (2001) Estimating wealth effects without expenditure data - or tear: an application to educational enrolments in states of India. Demography 38, $115-132$. 
29. Victora CG, Huttly SR, Fuchs SC et al. (1997) The role of conceptual frameworks in epidemiological analysis: a hierarchical approach. Int I Epidemiol 26, 224-227.

30. Souza OF, Benício MHDA, Castro TG et al. (2012) Desnutrição em crianças menores de 60 meses em dois municípios no Estado do Acre: prevalência e fatores associados. Rev Bras Epidemiol 15, 1-11.

31. Monteiro CA, Benicio MH, Conde WL et al. (2010) Narrowing socioeconomic inequality in child stunting: the Brazilian experience, 1974-2007. Bull World Health Organ 88, 305-311.

32. Kramer MS (2003) The epidemiology of adverse pregnancy outcomes: an overview. J Nutr 133, Suppl. 2, 1592S-1596S.

33. Black RE, Allen LH, Bhutta ZA et al. (2008) Maternal and Child Undernutrition Study Group. Maternal and child undernutrition: global and regional exposures and health consequences. Lancet 371, 243-260.

34. Ozaltin E, Hill K \& Subramanian SV (2010) Association of maternal stature with offspring mortality, underweight, and stunting in low- to middle-income countries. JAMA 303 , $1507-1516$

35. Castro TG, Nunes MS, Conde WL et al. (2011) Anaemia and iron deficiency among schoolchildren in the Western Brazilian Amazon. Cad Saude Publica 27, 131-142.

36. Scrimshaw NS (2010) INCAP studies of nutrition and infection. Food Nutr Bull 31, 54-67.

37. Martins PA, Hoffman DJ, Fernandes MTB et al. (2004) Stunted children gain less lean body and more fat mass than their non-stunted counterparts: a prospective study. Br J Nutr 92, 819-825.

38. Hoffman DJ, Martins PA, Roberts S et al. (2007) Body fat distributions in stunted compared with normal-height children from the shantytowns of São Paulo, Brazil. Nutrition 23, 640-646.

39. McDonald CM, Baylin A, Arsenault JE et al. (2009) Overweight is more prevalent than stunting and is associated with socioeconomic status, maternal obesity, and a snacking dietary pattern in school children from Bogota, Colombia. J Nutr 139, 370-376.

40. Wang Y (2001) Cross-national comparison of childhood obesity: the epidemic and the relationship between obesity and socioeconomic status. Int J Epidemiol 30, 1129-1136.

41. Shrewsbury V \& Wardle J (2008) Socioeconomic status and adiposity in childhood: a systematic review of crosssectional studies 1990-2005. Obesity (Silver Spring) 16, 275-284.

42. Goldani HA, Bettiol H, Barbieri MA et al. (2011) Cesarean delivery is associated with an increased risk of obesity in adulthood in a Brazilian birth cohort study. Am J Clin Nutr 93, 1344-1347.

43. Vieira TO, Vieira GO, Giugliani ER et al. (2010) Determinants of breastfeeding initiation within the first hour of life in a Brazilian population: cross-sectional study. BMC Public Health 10, 760.

44. Yu ZB, Han SP, Zhu GZ et al. (2011) Birth weight and subsequent risk of obesity: a systematic review and metaanalysis. Obes Rev 12, 525-542.
45. Hirschler V, Bugna J, Roque M et al. (2008) Does low birth weight predict obesity/overweight and metabolic syndrome in elementary school children? Arch Med Res 39, 796-802.

46. Cnattingius S, Villamor E, Lagerros YT et al. (2011) High birth weight and obesity - a vicious circle across generations. Int J Obes (Lond) 13, 1-5.

47. Nead KG, Halterman JS, Kaczorowski JM et al. (2004) Overweight children and adolescents: a risk group for iron deficiency. Pediatrics 114, 104-108.

48. Pinhas-Hamiel O, Newfield RS, Koren I et al. (2003) Greater prevalence of iron deficiency in overweight and obese children and adolescents. Int J Obes Relat Metab Disord 27, 416-418.

49. del Giudice EM, Santoro N, Amato A et al. (2009) Hepcidin in obese children as a potential mediator of the association between obesity and iron deficiency. J Clin Endocrinol Metab 94, 5102-5107.

50. Cook JD, Baynes RD \& Skikine BS (1992) Iron deficiency and the measurements of iron status. Nutr Res Rev 2, 189-202.

51. Garcia MT, Granado FS \& Cardoso MA (2010) Complementary feeding and nutritional status of 6-24 month-old children in Acrelândia, Acre State, Western Brazilian Amazon. Cad Saude Publica 27, 305-316.

52. Dubois L \& Girard M (2006) Early determinants of overweight at 4.5 years in a population-based longitudinal study. Int J Obes (Lond) 30, 610-617.

53. Jääskeläinen A, Pussinen J, Nuutinen $\mathrm{O}$ et al. (2011) Intergenerational transmission of overweight among Finnish adolescents and their parents: a 16-year followup study. Int J Obes (Lond) 35, 1289-1294.

54. Salvy SJ, Elmo A \& Nitecki LA (2011) Influence of parents and friends on children's and adolescents' food intake and food selection. Am J Clin Nutr 93, 87-92.

55. Toprak D, Toprak A, Chen W et al. (2011) Adiposity in childhood is related to C-reactive protein and adiponectin in young adulthood: from the Bogalusa Heart Study. Obesity (Silver Spring) 19, 185-190.

56. Vio F, Albala C \& Kain J (2008) Nutrition transition in Chile revisited: mid-term evaluation of obesity goals for the period 2000-2010. Public Health Nutr 11, 405-412.

57. Instituto Brasileiro de Geografia e Estatística (2010) Pesquisa de Orçamentos Familiares 2008-2009. Aquisição alimentar domiciliar per capita. Rio de Janeiro: IBGE.

58. Mikkila V, Räsänen L, Raitakari OT et al. (2007) Major dietary patterns and cardiovascular risk factors from childhood to adulthood. The Cardiovascular Risk in Young Finns Study. Br J Nutr 98, 218-225.

59. Wang Y, Bentley ME, Zhai F et al. (2002) Tracking of dietary intake patterns of Chinese from childhood to adolescence over a six-year follow-up period. J Nutr $\mathbf{1 3 2}$, 430-438.

60. Scagliusi FB, Garcia MT, Indiani AL et al. (2011) Relative validity of a food-frequency questionnaire developed to assess food intake of schoolchildren living in the Brazilian Western Amazon. Cad Saude Publica 27, 2197-2206. 